\title{
Consumers' preferences for smocked utility articles
}

\author{
SHIKHA BAJAJ AND HARMINDER KAUR SAINI
}

Received: 18.07.2014; Revised: 22.10.2014; Accepted: 06.11.2014

See end of the paper for authors' affiliations

\section{HARMINDER KAUR SAINI}

Department of Apparel and

Textile Science, College of Home

Science, Punjab Agricultural

University, LUDHIANA (PUNJAB)

INDIA

Email: harsaini67@yahoo.com
ABSTRACT : The craftsmanship of embroidery has its own excellence, attracting people from all parts of the world. In the present fashion world, embroidered pieces are preferred by everyone. The beautiful art of smocking fills delicacy and elegance to the fabric pieces and gives them a worthy place in fashion market. The present investigation was carried out in Ludhiana city. An interview schedule was prepared for the purpose of collecting the data from 90 female respondents between age group of 20-40 years selected randomly from three localities of Ludhiana city. The results of the study revealed that among the identified utility articles for smocking, cushion cover was the most preferred article (15.49) followed by handbag (14.36), bolster cover (13.21), folder (12.69), lampshade (12.46), footwear (12.33), pillow cover (11.66), jewellery box (11.61), curtain canopies (11.50) and trimming for bedsheet (9.98). Plain fabric without design was most preferred. Single coloured fabric was the most preferred followed by two coloured combination. Cotton yarn was most preferred by the respondents for smocking stitches followed by blended fabric. In case of embellishments, laces and beads were preferred the most. Pillow cover was the most preferred article on the basis of suitability of yarn and utility. Cushion cover was preferred the most on the basis of design, colour and overall impact and jewellery box was the most preferred article on the basis of embellishments used.

KEY WORDS: Smocking, Articles, Utility, Preferences

- HOW TO CITE THIS PAPER : Bajaj, Shikha and Saini, Harminder Kaur (2014). Consumers' preferences for smocked utility articles. Asian J. Home Sci., 9 (2) : 505-508. 